\title{
Description of the postembryonic stages of Boeckella poopoensis (Crustacea, Copepoda, Centropagidae)
}

\author{
Gabriela C. Cabrera' (D) https://orcid.org/0000-0002-0399-0324 \\ Alicia M. Vignatti' (1) https://orcid.org/0000-0002-7571-4310 \\ Santiago A. Echaniz' (D) https://orcid.org/0000-0002-8857-5348 \\ Alicia H. Escalante ${ }^{2,3}$
}

\author{
1. Universidad Nacional de La Pampa, Facultad de Ciencias Exactas y Naturales. Uruguay 151 L6300CLB Santa Rosa, La Pampa. Argentina. \\ (gabrielacabrera@exactas.unlpam.edu.ar) \\ 2. Universidad Nacional de Mar del Plata, Facultad de Ciencias Exactas y Naturales. Dean Funes 3350 B7600 Mar del Plata, Buenos Aires, Argentina \\ 3. Consejo Nacional de Investigaciones Cientíícas y Técnicas. Av. Godoy Cruz 2290 C1425FQB Ciudad Autónoma de Buenos Aires, Buenos Aires, Argentina.
}

Received 21 November 2017

Accepted 23 March 2018

Published 11 June 2018

DOI 10.1590/1678-4766e2018010

\begin{abstract}
Boeckella poopoensis Marsh, 1906 is one of the most common copepods in the saline lakes of South America, where generally is the species that greater contributes to the zooplankton community biomass. Despite of its wide geographic distribution and ecological importance, the characteristics of the postembryonic stages are unknown, which prevents a detailed understanding of the structure and dynamics of natural populations. The objective of this work was to describe the morphology of the postembryonic stages and to compare it with other species of Centropagidae. The specimens were obtained from a monospecific culture acclimatized in the laboratory. The lineage comes from El Carancho shallow lake $\left(65^{\circ} 03^{\prime} \mathrm{W}, 37^{\circ} 27^{\prime} \mathrm{S}\right)$. The identification of the postembryonic stages was performed according to the characteristics established for copepod calanoids. Based in all developing stages, some characteristics that distinguish B. poopoensis from another species of the genus are: lobes of nauplii with the same number of setae of equal length; beginning of body segmentation from nauplii III; sexual dimorphism from copepodite IV (although only evident in the V leg); the endopod of the V leg of copepodites $\mathrm{V}$ males and females are biarticulate, but while females endopod add setae respect to the previous stage, males endopod lose them and remain glabrous as in the adults. Copepodites V do not present characteristics typical of adults, such as, the most developed thoracic left wing of females and in the geniculate right antenna of males. All stages of $B$. poopoensis are larger than those corresponding to other species of centropagids, and in the immature stages, the appendages show their own patterns of setae and have a slightly smaller number of setae than that of the other species of the family.
\end{abstract}

KEYWORDS. Calanoid copepods, Neotropical centropagids, nauplii larvae, copepodite stages.

RESUMEN. Descripción de los estadios postembrionarios de Boeckella poopoensis (Crustacea, Copepoda, Centropagidae). Boeckella poopoensis Marsh, 1906 es uno de los copépodos más frecuentes en el zooplancton de los lagos salinos sudamericanos, donde generalmente es la especie que más contribuye a la biomasa de la comunidad zooplanctónica. A pesar de su amplia distribución geográfica y su importancia ecológica, las características que distinguen sus estadios postembrionarios no son conocidas, lo que no permite conocer detalladamente la estructura y dinámica de sus poblacionales naturales. El objetivo de este trabajo fue describir la morfología de los estadios postembrionarios y compararlos con los de otras especies de Centropagidae. Los especímenes estudiados fueron obtenidos de un cultivo monoespecífico aclimatado en laboratorio. El linaje proviene del lago El Carancho ( $65^{\circ} 03^{\prime} \mathrm{W}$, $\left.37^{\circ} 27^{\prime} \mathrm{S}\right)$. La identificación de los estadios se hizo de acuerdo a los caracteres establecidos para los copépodos calanoideos. En base a todos los estados de desarrollo, algunas de las características que distinguen a B. poopoensis de otras especies del género son: lóbulos de los nauplios con el mismo número de sedas de igual longitud; la segmentación del cuerpo se inicia en el estadio de nauplio III; el dimorfismo sexual empieza a notarse a partir del copepodito IV (aunque sólo es evidente en la pata V); el endopodito de la pata V de los copepoditos $\mathrm{V}$ machos y hembras es biarticulado pero, mientras las hembras adquieren sedas con respecto al estadio anterior, los machos las pierden, llegando a ser glabras como en los adultos. Los copepoditos V no presentan características típicas de los adultos, tales como, el ala toracal izquierda más desarrollada en las hembras y la antena derecha geniculada en los machos. Todos los estadios de B. poopoensis son más grandes que los correspondientes a otros centropágidos y los estadios inmaduros muestran su propio patrón de sedas, con un número ligeramente menor que el de otras especies de la familia.

PALABRAS CLAVE. Copépodos calanoideos, centropágidos neotropicales, larva nauplio, estadio copepodito.

The copepod juvenile stages constitute $60 \%$ to $80 \%$ of the natural population and thus play an important role in the circulation of the energy and matter cycle of planktonic communities (FrYER, 1987; ZINKAI, 1991, 1994). In ecological studies, naupliar and copepodite instars are often considered a unit (TrujILlo-OrTIZ, 1986). The juvenile stage simplification (grouping all the naupliar or copepodite stages together) makes it possible to analyze the copepods population. However, it does not allow obtaining a detailed understanding of the structure and dynamics of natural 
populations and their relationships with environmental parameters, much less when more than one species from the same genus coexist in an ecosystem.

Few research studies have focused on continental copepod development. Among them, one study was conducted by FAIRBRIDGE (1945) on Boeckella opaqua Fairbridge, 1945, a calanoid species from Australia. CHAPMAN \& BURNs (1976) compared the IV and V copepodite stages from five calanoid species. CZAIKa (1982) developed keys for naupliar and copepodite instar identification from 12 calanoid (does not include species of Boeckella) and cyclopoid species from the Great Salt Lake of Utah to facilitate their recognition in the stomach content of fish, and JERSABEK et al. (1996) studied the naupliar development of the calanoid Acanthodiaptomus denticornis (Wierzejski, 1887) and Arctodiaptomus alpinus (Imhof, 1885).

Some studies were conducted in South America. For example, Cicchino (1972) characterized Notodiaptomus coniferoides (Wright S., 1927) naupliar development. NAVARRo-Cirólli (1973) described the external morphology of Scolodiaptomus corderoi (Wright S., 1936) postembryonic stages, and PIRES DE GouvÉA (1980) characterized Notodiaptomus conifer (Sars, 1901) naupliar instars. Still, a description of the postembryonic development of copepod calanoid from South American epicontinental waters has received little attention in the literature.

In the particular case of Boeckella De Guerne \& Richard, 1889, the publication of FAIRBRIDGE (1945) is one of the earliest and scarcest contributions in which the larval stages of one Australian species were identified and characterized. More recently, JAMIESON (1986) investigated the more conspicuous characteristics that distinguish female adults and the advanced copepodite stages of three endemic species of Boeckella from Australasia; however, a contribution that describes the postembryonic stages of species from the genus from the Neotropical region is lacking.

The calanoid of the family Centropagidae, Boeckella poopoensis Marsh, 1906, is a predominant crustacean species found in lakes with high salinity (DE LOS Ríos \& Contreras, 2005; De los Ríos-Escalante, 2011; VignatTi et al., 2016). It has a broad geographical distribution from the north of the Patagonian plateau in Argentina and Chile to the south of Peru (Menú-MarQue et al., 2000). It is widely tolerant to several environmental factors, as it can live in saline, hypertrophic conditions, or with a high suspended inorganic solid concentration in lakes. Frequently is the species that greater density and biomass contributes to the zooplankton community of these lakes (EcHANIz et al., 2013; VignatTi et al., 2016). The original description of $B$. poopoensis was presented in 1906 by Charles Dwight Marsh from specimens belonging to Poopó and the Titicaca lakes, and it was published in the Neveu-Lamaire (1906) study on South American high plateau lakes. This description was done, as has frequently occurred in copepod traditional taxonomy, only according to distinctive female and male adult characteristics, among which the importance of the $\mathrm{V}$ pair of legs is highlighted. This led Marsh to describe and schematize the morphology, setation, and spine number of these appendages in both sexes.

Given the wide geographical distribution and importance of B. poopoensis and the lack of information regarding the distinctive characteristics of its different larval stages, the aims of the present work were to describe 11 postembryonic stages, to compare them with the other species of Centropagidae, such as the Australian B. opaqua and the estuarine Gladioferens pectinatus (Brady, 1899), and to identify their primary differences.

\section{MATERIALS AND METHODS}

\section{Obtention of Boeckella poopoensis population.}

Adult specimens were isolated from an open-air mesocosm, inoculated with sediment collected in El Carancho shallow lake $\left(65^{\circ} 03^{\prime} \mathrm{W}, 37^{\circ} 27^{\prime} \mathrm{S}\right)$, and acclimated in the laboratory. They were placed in $10 \mathrm{~L}$ aquaria and incubated for three months at $22 \pm 1{ }^{\circ} \mathrm{C}$ and a photoperiod of $16: 8$ hours (light:darkness) (GutiÉRrez et al., 2010). The medium was renewed periodically, and Dunaliella salina (Teodoresco, 1905) (ad libitum) was added as food to allow for reproduction.

Identification of $B$. poopoensis postembryonic stages. After acclimation, five samples of $100 \mathrm{~mL}$ were taken from aquaria, anesthetized with $\mathrm{CO}_{2}$ to avoid specimen deformation, and preserved in $70 \%$ alcohol. Subsamples of $1 \mathrm{~mL}$ were placed in Sedgwick-Rafter chambers, and each of the postembryonic stages was determined under a light microscope. Specimens were mounted on slides, and the description and microphotographies of each instar were carried out using a conventional optic microscope equipped with an Arcano 3.0 video chamber. Different measurements were performed using a 10X Arcano ocular micrometer.

The identification of the postembryonic stages was done according to the characteristics established for copepod calanoids (FAirbridge, 1945; RAVERA, 1953; CicCHINO, 1972; Navarro-Cipólli, 1973; Chapman \& Burns, 1976; Pires de GouvÉA, 1980; MCKinNON \& ARnOTt, 1985). In all cases, dissections of at least ten specimens per stage were performed. The characteristics selected to identify the naupliar stages were: corporal size, number and pattern of setae of the antennula, antenna, maxillule, maxilla, maxilliped, and the outlines of swimming legs and the caudal structure. For copepodite identification, corporal size, the segment number of the cephalothorax and abdomen, the number of swimming legs, the number and pattern of furcal setae, and the number of antennula segments were considered. In addition, for IV and V copepodites, dissections of V legs in at least ten specimens were performed to differentiate between males and females.

All schemes were carried out using the microphotographies of the postembryonic stages and their different appendages and through comparisons with the studies conducted by FAIRBRIDGE (1945), RAVERA (1953), 
Cicchino (1972), Navarro Cipólli (1973), Chapman \& Burns (1976), Pires de Gouvéa (1980), McKinnon \& Arnott (1985) and Huys \& Boxshall (1991).

The specimens were deposited in the plankton collection of the Facultad de Ciencias Exactas y Naturales de la Universidad Nacional de La Pampa (Argentina) under the denomination PICB No 245.

\section{RESULTS}

Nauplius I. Length: $214.1 \pm 20.4 \mu \mathrm{m}(\mathrm{n}=214)$.

Body typically pyriform. Posterior region rounded, with two furcal setae of equal length. The appendages present at this stage are antennula, antenna, and mandible.

Antennula: uniramous appendage formed by three segments. Terminal segment has three plumose apical setae, whose number and position are the same in the remainder of the naupliar stages. The second segment has two setae, one apical and the other in the middle, while the first segment has one short seta similar to a hook (Fig. 1).

Antenna: biramous appendage formed by a glabrous coxopod, and a basipod with one seta in the middle. Endopod with two plumose apical setae and two lateral setae of equal length. Exopod with five segments: the terminal one has two dissimilar setae (the internal is about twice as long as the external), while each of the other segments has one plumose seta (Fig. 2).

Mandible: biramous appendage formed by a more or less oval coxopod with one seta. Basipod with two setae slightly separated from each other. Endopod of almost oval shape and five setae: one lateral and four apical (the two external are longer and of dissimilar length, and the two internal are shorter, of equal length, and very close to each other). Exopod four-segmented: the terminal segment has two plumose setae of different lengths, and the remaining segments have one long plumose seta (Fig. 3).

Nauplius II. Length: $256.3 \pm 19.3 \mu \mathrm{m}(\mathrm{n}=217)$.

In the rear extreme of the body, furcal lobe outlines were observed, each with a terminal seta. This instar has the same number of appendages as nauplius I.

Antennula: in their internal and external edges, the distal segment has a row of small setae, and at the distal edge, four short setae, surpassing the insertion of the three plumose apical setae of the appendage, were observed. The first segment has one seta that loses its hook shape, unlike nauplius I, while the second segment maintains the same number and pattern of setae as in nauplius I (Fig. 4).

Antenna: coxopod with a fine basal seta. Basipod with two setae, one stronger and plumose, located in the basal mid-zone, and the other finer in the distal mid-zone. Endopod with three apical setae of growing length and with two lateral setae of equal length and close to each other. Exopod with seven long plumose setae. The distal segment has two apical and the other segments only one, except the basal segment, which has two (Fig. 5).

Mandible: coxopod, basipod, and exopod conserve the same pattern and number of setae as nauplius I. Endopod has seven plumose setae and five apical (the three longer ones are located close to each other, and the two lateral are in the middle of the segment) (Fig. 6).

Under the mandible, in the lower mid-region of the body, three rows of short setae were observed, one under the other.

Nauplius III. Length: $300.5 \pm 16.8 \mu \mathrm{m}(\mathrm{n}=253)$.

Body segmentation visible. Furcal lobes welldifferentiated, each with two terminal setae, one noticeably thicker than the other. Both setae surrounded by three rows of shorter setae. In this instar, a new pair of appendages is added: the maxillule.

Antennula: the distal segment with two external setae, one plumose and closer to the apex, and other glabrous and noticeably shorter, while the inner side has only one glabrous seta. In the second segment, the apical seta expands, surpassing the distal segment of the antenna (Fig. 7).

Antenna: coxopod with three setae, one located in the middle and the other two in the base, which are robust and close to each other. Basipod with a remarkable bilobulated outline and four setae. The basal is more plumose and robust and longer than the others. Endopod with three apical setae of growing lengths, and three lateral setae in the middle close to each other. Exopod with nine setae. The distal segment with three setae of growing lengths. The remaining segments with one seta each, except the first segment, which has three, the basal significantly shorter than the other two (Fig. 8).

Mandible: the coxopod with only one seta. Basipod with three setae in the middle next to each other. Endopod with eight setae: three apical, two lateral close to the apical, and the other three at the base of the article. Exopod with six setae, two in the distal and in the basal segments and one in each of the remaining segments (Fig. 9).

Maxillule: similar to a thick seta of a triangular base.

Nauplius IV. Length: $351.2 \pm 17 \mu \mathrm{m}(\mathrm{n}=282)$.

Body segmentation becomes more evident. This stage conserves the same number of appendages as nauplius III.

Antennula: the last third of the distal segment with three relatively short and glabrous setae on the inner side, while its outer side has four, two long and plumose and the other two shorter and glabrous. In addition, on the outer side of the segment, a row of small setae in the basal position was observed. The remaining antennula segments conserve the same number and pattern of setae as nauplius III (Fig. 10).

Antenna: the coxopod has a sub-squared shape and conserves the same number and pattern of setae. Basipod is markedly bilobed. Distal lobe with two setae and the basal with three dissimilar setae, with the basal being more robust and longer. Endopod with three apical setae, one subapical and three lateral in the middle close to each other. Exopod six-segmented with ten setae. The distal segment has three and the remaining segments one, except the basal segment has three setae, one long and plumose and the other two shorter and glabrous (Fig. 11).

Mandible: coxopod with an outline of the coxal process. Endopod with nine setae; four are apical, two lateral and close to the apical, and the other three are located in the 


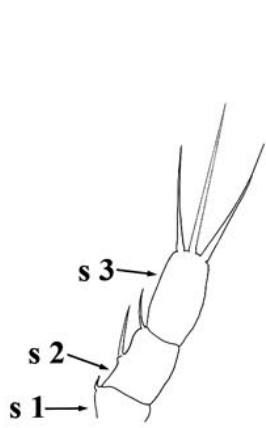

1

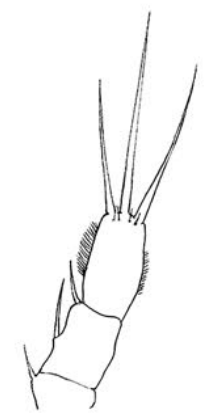

4

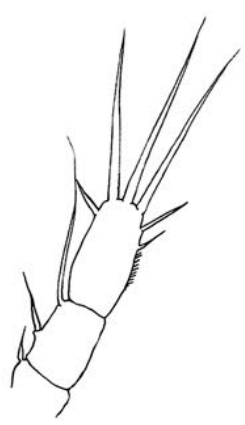

7

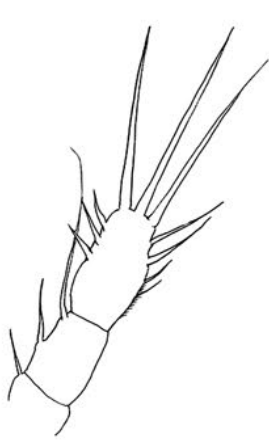

10

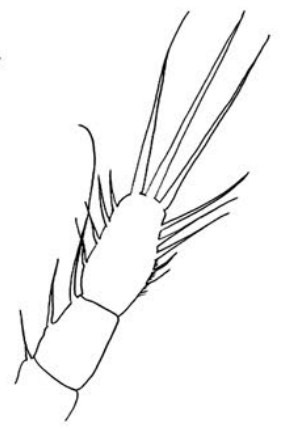

14

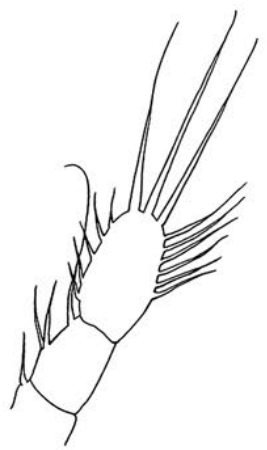

18

$\overline{50 \mu \mathrm{m}}$

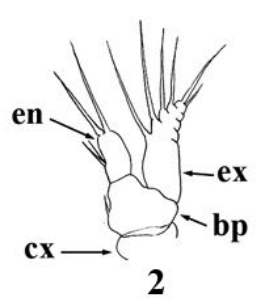

2

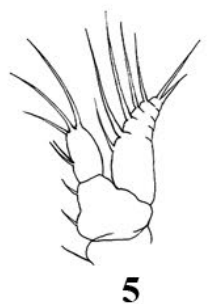

5

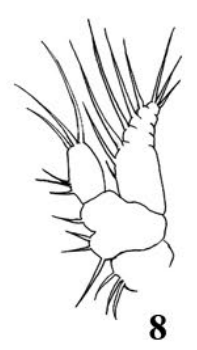

8

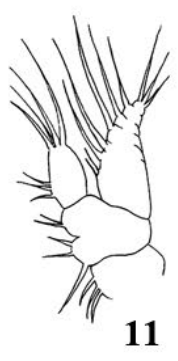

11

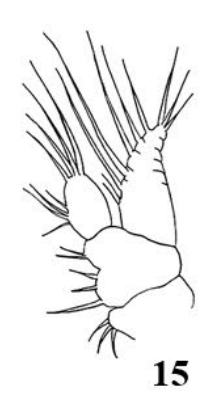

15

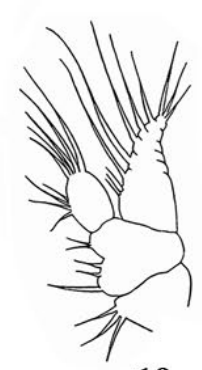

19

\section{$\overline{50 \mu \mathrm{m}}$}

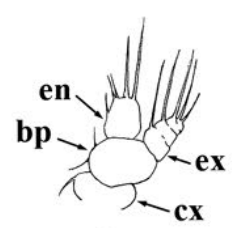

3

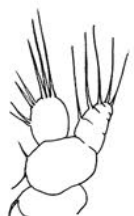

6

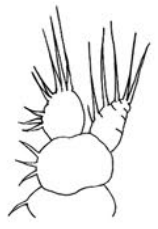

9

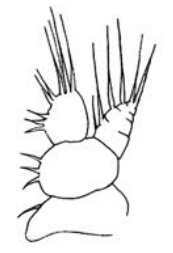

12

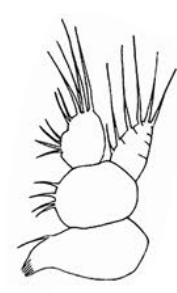

16

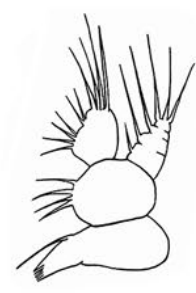

20

$\overline{\mathbf{5 0 \mu m}}$

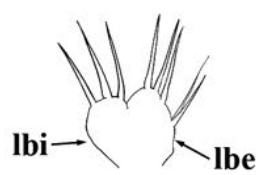

13

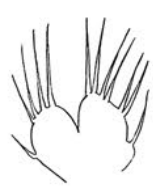

17

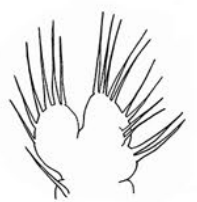

21

$\overline{20 \mu \mathrm{m}}$

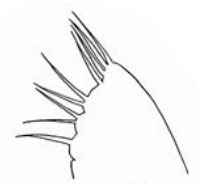

22

$\overline{20 \mu m}$

Figs 1-22. Appendages of Boeckella poopoensis naupliar stages. 1, 4, 7, 10, 14 and 18, antennula of nauplius I-VI; 2, 5, 8, 11, 15 and 19, antenna of nauplius I-VI; 3, 6, 9, 12, 16 and 20, mandible of nauplius I-VI; 13, 17 and 21: maxillule of nauplius IV-VI; 22, maxilla of nauplius VI (s1, segment 1; s2, segment 2; s3, segment 3; cx, coxopod; bp, basipod; en, endopod; ex, exopod; ilb, internal lobe; elb, external lobe). 
middle of the article. Basipod and exopod have the same number and pattern of setae as nauplius III (Fig. 12).

Maxillule: bilobed with eight plumose setae. The inner lobe has three apical setae, and the outer lobe has five, three apical and two located in the middle of the appendage (Fig. 13).

Nauplius V. Length: $408.5 \pm 26.8 \mu \mathrm{m}(\mathrm{n}=223)$.

Body segmentation is clearly evident. In this instar, a new pair of appendages is added immediately below the maxillule: the maxilla.

Antennula: inner edge of the distal segment with four glabrous setae, while the outer has five plumose setae of decreasing size toward the base of the article. On this side of the segment, a row of small setae was observed in the basal mid-position. All other segments of the antennula conserve the same number and pattern of setae as nauplius IV (Fig. 14).

Antenna: coxopod, basipod, and exopod maintain the same number and pattern of setae. Endopod with four apical setae and four lateral setae close to each other are located in the mid-zone of the segment (Fig. 15).

Mandible: coxopod with one seta and a well-developed coxal process. Basipod with four plumose setae in the middle of the segment. Endopod acquires a more or less rounded shape and has one notch. It has six setae in the distal part and four in the middle of the segment. Exopod conserves the same number and pattern of setae as nauplius IV (Fig. 16).

Maxillule: two lobes are clearly differentiated: the inner has five setae and the outer, which has a lobulated outline, with six setae at the major part (distal) and one seta at the minor area (basal) (Fig. 17). Maxilla unilobed with a small seta.

Nauplius VI. Length: $473.5 \pm 42.4 \mu \mathrm{m}(\mathrm{n}=243)$.

Clearly marked body segmentation. The other postmandibular appendages are added: the maxilliped and the first two pairs of swimming legs.

Antennula: the inner edge of the distal segment has five glabrous setae, and the outer has six plumose setae of decreasing size toward the basal part. The second segment has three glabrous setae, one long and apical and the other two close to each other in the middle of the article. The first segment conserves the same number and pattern of setae as nauplius V (Fig. 18).

Antenna: coxopod and basipod maintain the same number and pattern of setae. Endopod has five apical setae and four lateral located in the middle of the segment. Exopod with 11 setae, three in the distal segment and the others one per segment, except the basal segment, which has four. One is long and plumose, and the other three are noticeably shorter and glabrous (Fig. 19).

Mandible: conserves the same number and pattern of setae as nauplius V (Fig. 20).

Maxillule bi-segmented, the distal segment bilobed, the inner with six setae, and the outer with a lobulated outline and 11 setae, nine of which located in the major part (distal) of the lobe and the other two in the minor (basal). The basal segment with a long apical seta (Fig. 21).
Maxilla: only one segment and nine setae on the inner side (Fig. 1).

Maxilliped unilobed with two strong terminal setae (Fig. 22).

I pair of legs bilobed, the inner lobe has three terminal setae, and the outer four.

II pair of legs bilobed, the inner lobe has two terminal setae, and the outer has three.

Copepodite I. Length: $645.6 \pm 62.3 \mu \mathrm{m}(\mathrm{n}=240)$.

Cephalothorax four-segmented. In this stage, as well as in the remaining copepodite stages, segment 1 has all the pre- and post-masticatory appendages: antennula, antenna, mandible, maxillule, maxilla, and maxilliped. Segments 2 and 3 with one pair of functional swimming legs, while in segment 4 , the outline of the third pair of swimming legs is observed. Abdomen two-segmented. The caudal structure presents two branches, each with three plumose terminal setae, two of which are internal and long and the other external and noticeably shorter (Fig. 23). Antenna with ten segments.

Copepodite II. Length: $782.6 \pm 79.2 \mu \mathrm{m}(\mathrm{n}=216)$.

Cephalothorax five-segmented. Segments 2, 3, and 4 each with a pair of swimming legs. In segment 5 , the outline of the fourth pair of legs is observed. Abdomen twosegmented, each furcal branch with five long and plumose setae, the external noticeably shorter. Inner side of the furcal branches, with a short and glabrous seta (Fig. 24). Antenna with 18 segments.

Copepodite III. Length: $960.3 \pm 98.8 \mu \mathrm{m}(\mathrm{n}=228)$.

Cephalothorax formed by six segments. Segments 2 , 3,4 , and 5 each with a pair of swimming legs. In segment 6 , the outline of the fifth pair of legs was observed. Abdomen two-segmented, and the number and pattern of furcal setae are the same as for copepodite II (Fig. 25). Antenna has 22 segments.

Copepodite IV. Length: $1171.7 \pm 110.4 \mu \mathrm{m}(\mathrm{n}=227)$. In this stage, there are five pairs of swimming legs, and the fifth is noticeably shorter than the others. Abdomen threesegmented. Each furcal branch has five long and plumose setae of increasing length toward the inner area, and the internal face maintains a short and glabrous seta (Fig. 26). Antenna with 25 segments.

Sexual dimorphism not clearly distinguished. The sex only can be differentiated by dissecting the $\mathrm{V}$ pair of legs.

$\mathrm{V}$ pair of legs 9 : coxopod and basipod of sub-squared shape, comparatively stronger in relation to the $\mathrm{V}$ pair of the male. Endopod with two long terminal setae. Laterally, it has three setae on the inner side and one on the outer side. Exopod one-segmented. Laterally, on both sides, it has two setae, with the external side shorter and stronger. In the apical zone, the exopod has three setae, being the central middle grosser and longer than the other two (Fig. 27).

$\mathrm{V}$ pair of legs ${ }^{\lambda}$ : coxopod and basipod of an almost trapezoidal shape. Endopod one-segmented with two long setae close to each other in the distal extreme and two fine setae on its inner side. Exopod one-segmented with two terminal setae, the inner noticeably longer than the outer. 


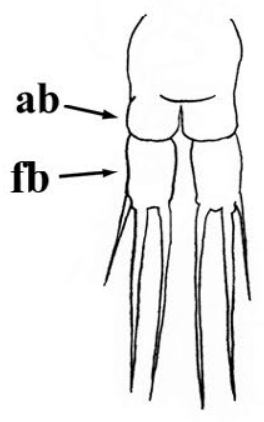

23

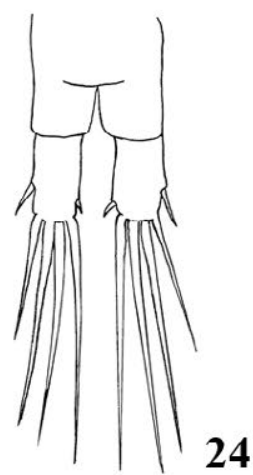

24

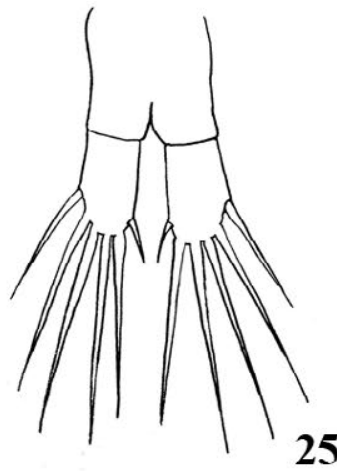

25

$\overline{100 \mu m}$

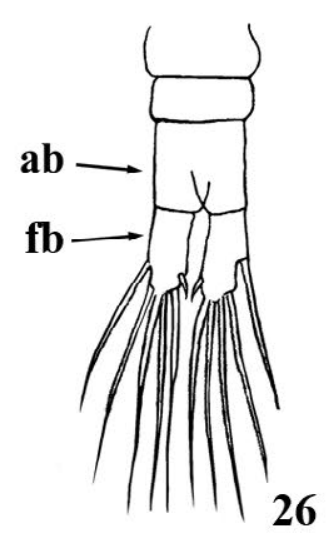

$\overline{100 \mu \mathrm{m}}$

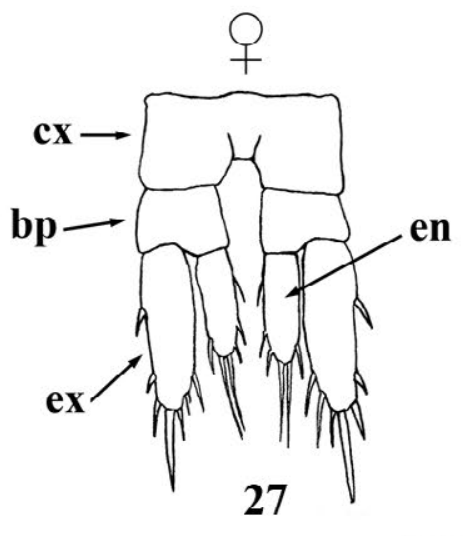

27

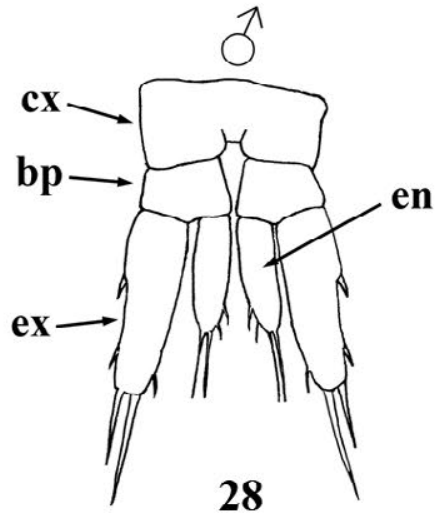

28

$100 \mu \mathrm{m}$

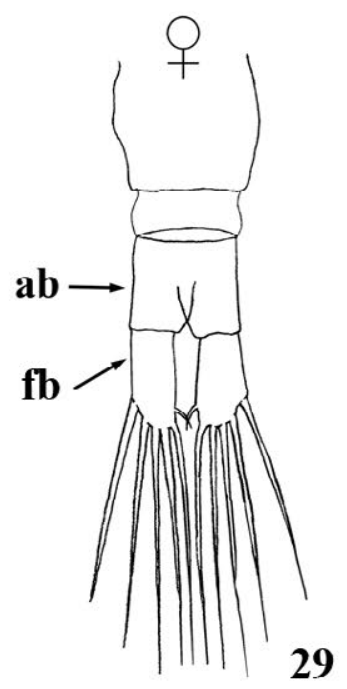

$\overline{100 \mu \mathrm{m}}$

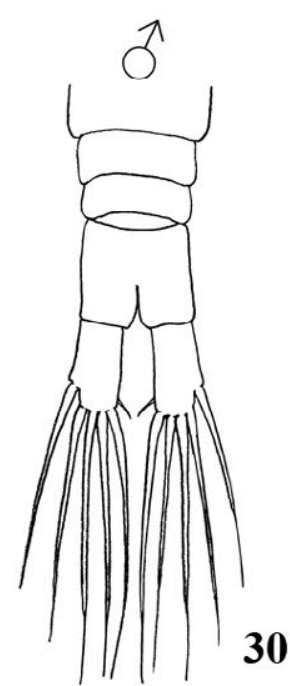

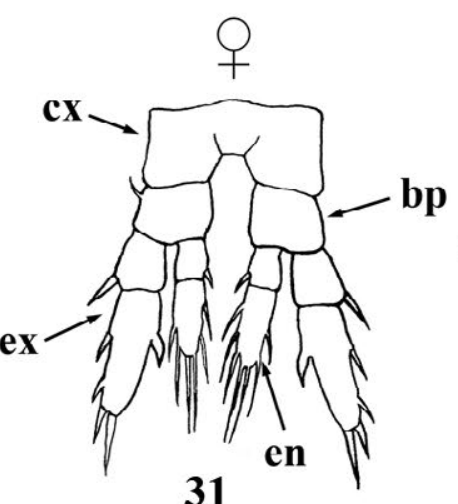

31

30

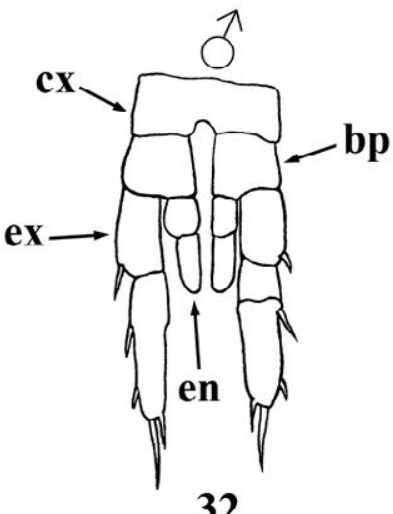

32 $\overline{100 \mu \mathrm{m}}$

Figs 23-32. Abdomen, furcal setae and V pair of legs of Boeckella poopoensis copepodite stages. 23 to 25, furcal setae of copepodite I-III; 26, abdomen and furcal setae of copepodite IV; 27, V pair of legs of copepodite IV $\$$; 28, V pair of legs of copepodite IV $3 ; 29$, abdomen and furcal setae of copepodite

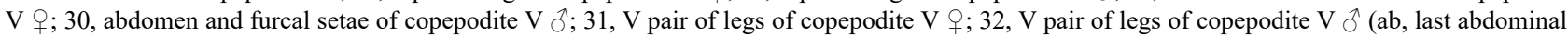
segment; fb, furcal branch; cx, coxopod; bp, basipod; en, endopod; ex, exopod). 
Laterally, on the inner side, it has one seta located near the apical zone, while on the outer side, it has two short setae (Fig. 28).

Copepodite V. + length: $1483.4 \pm 206.2 \mu \mathrm{m}(\mathrm{n}=$ 175); đ̂ length: $1337.4 \pm 104.6 \mu \mathrm{m}(\mathrm{n}=163)$.

Both sexes with five pairs of swimming legs of almost equal length. The number and pattern of the furcal setae are the same as for copepodite IV (Figs 29, 30). Antennula with 25 segments.

In this stage, the sexual dimorphism is evident, and both sexes can be clearly distinguished. The more distinguishable characteristics are the number and the width of the abdominal segments. Females have three segments, with the first noticeably wider than the others (Fig. 29), while males have four segments of almost equal width, with the first narrower than that of females (Fig. 30).

$\mathrm{V}$ pair of legs $q$ : coxopod and basipod of sub-squared shape, comparatively stronger than those of males. Basipod with a small basal seta. Endopod two-segmented, the distal with two long terminal setae. Laterally, three setae on the inner side, and two on the outer side, while the basal segment has one mid-apical seta on its outer side. Exopod two-segmented. Distal segment with two strong terminal setae, the inner longer than the outer. Laterally, on the outer side two gross setae, and on the inner side, one strong seta at the mid-basal position. The basal segment has one gross apical seta (Fig. 31).

$\mathrm{V}$ pair of legs $\delta$ : the left leg slightly longer than the right. Coxopod and basipod with a sub-squared shape. Endopod two-segmented and without setae. Basal segment of the left leg with more or less rounded shape, while the distal segment, as well as both segments of the right leg, are of almost rectangular shape. Exopods of the right and left leg three- and two-segmented, respectively. The distal segment of both legs with two apical setae, the external grosser than the internal, and laterally, on its outer side, it has two setae. The basal segment with only one apical seta. The second segment of the right leg relatively small and glabrous (Fig. 32).

\section{DISCUSSION}

Until now, a description of the development stages of Boeckella opaqua, a freshwater calanoid that is endemic to Australasia (FAIRBRIDGE, 1945), was the only characterization made for a species of this genus. The description of the postembryonic stages of $B$. poopoensis, though it is the second contribution to the genus, represents the first carried out on a species of Boeckella endemic to the Neotropical region.

Although it is known that the corporal length of copepods is a parameter that can be affected by different variables, such as food and temperature (CHAPMAN \& BURNS, 1976; BAN, 1994), this was one of the most relevant characteristics that allowed for distinguishing between $B$. poopoensis and the other species under comparison. All its postembryonic stages reached a higther corporal size, at about $25 \%$ greater than B. opaqua and $40 \%$ than that the estuarine Gladioferens pectinatus (Tab. I).

Other differences were observed in the caudal structure. For instance, each furcal lobe of B. poopoensis nauplii has the same number of setae of equal length, unlike G. pectinatus, which also has the same number of setae but of dissimilar length, and B. opaqua, which has a different number of setae of dissimilar length on each lobe.

During copepodite development, these species also differ, as in B. opaqua and G. pectinatus the two former, the final number of furcal setae is gradually acquired, while in B. opaqua, the copepodite I caudal structure already presents the same number of setae as in that of copepodite V (Tab. I).

The corporal segmentation of $B$. poopoensis and $G$. pectinatus begins in nauplius III, while in $B$. opaqua occurs later in nauplius V; however, the postmandibular appendages become visible early, such as the rows of small setae in the estuarine species only (Tab. I).

The number of setae from naupliar appendages is relatively similar in the three calanoids, though $B$. poopoensis has a slightly smaller number (Tab. I).

The number of cephalothorax and abdomen segments from copepodite I differs among species. Boeckella poopoensis has four cephalothoracic and two abdominal segments, as does $G$. pectinatus, but $B$. opaqua has five in the cephalothorax and only one in the abdomen (Tab. I).

On the other hand, although FAIRBRIDGE (1945) did not specify the number of cephalothoracic segments of $B$. opaqua copepodite $\mathrm{V}$, it can be observed in his figures that the females have only five segments. This characteristic noticeably differs not only from $B$. poopoensis and $G$. pectinatus but also from other centropagid species (CHAPMAN \& Burns, 1976; MCKinnon \& ARnOTT, 1985). Six segments is characteristic in this stage, as in the first, all pre- and postmasticatory appendages are present. Each of the other stages includes one pair of swimming legs; however, it should be noted that in the copepodite IV figure by FAIRBRIDGE (1945), B. opaqua has six cephalothoracic segments, and thus it could be presumed that the smaller number of copepodite $\mathrm{V}$ could be incorrect.

The fifth pair of legs from the boeckellid copepodite IV and V are similar, and they noticeably differ from $G$. pectinatus. The fifth pair of legs from $G$. pectinatus copepodite IV did not show a difference in the number of setae between males and females, and the right and left legs of the fifth pair from copepodite $\mathrm{V}$ males are equal in seta and segment number, as both exopods are bi-segmented. Contrarily, in copepodite IV, cogeneric species have differences in the number of setae from the $\mathrm{V}$ pair of legs, and the right and left legs of the copepodite $\mathrm{V}$ male are different, as they have a different seta number. The left exopod legs are bi-segmented, while the right legs are three-segmented (Tab. I).

Another similarity found among the Boeckella species is that copepodite $\mathrm{V}$ acquires the same number of segments, unlike G. pectinatus, which has one less segment in the same stage (Tab. I). 
Tab. I. Comparison of the main morphological features of the postembryonic stages of Boeckella poopoensis Marsh, 1906, Boeckella opaqua Fairbridge, 1945 y Gladioferens pectinatus (Brady, 1899).

\begin{tabular}{|c|c|c|c|c|c|}
\hline & & & B. poopoensis & B. opaqua & G. pectinatus \\
\hline & & & \multicolumn{3}{|c|}{ Nauplius I } \\
\hline \multicolumn{3}{|c|}{ Corporal length } & $214,1 \mu \mathrm{m}$ & $165,5 \mu \mathrm{m}$ & $90 \mu \mathrm{m}$ \\
\hline \multicolumn{3}{|c|}{ Segmentation } & No & No & No \\
\hline \multirow{4}{*}{ 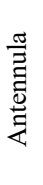 } & $\mathrm{N}^{\mathrm{o}}$ of articles & & 3 & 3 & 3 \\
\hline & $\mathrm{N}^{\mathrm{o}}$ of setae & Segment 1 & 1 & 1 & 0 \\
\hline & & Segment 2 & 2 & 2 & 3 \\
\hline & & Segment 3 & 3 & 3 & 3 \\
\hline \multirow{4}{*}{ 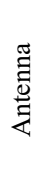 } & $\mathrm{N}^{\mathrm{o}}$ of setae & Coxopod & 0 & 1 & 2 \\
\hline & & Basipod & 1 & 3 & 3 \\
\hline & & Endopod & 4 & 4 & 4 \\
\hline & & Exopod & 6 & 6 & 6 \\
\hline \multirow{4}{*}{ 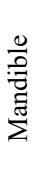 } & $\mathrm{N}^{\mathrm{o}}$ of setae & Coxopod & 1 & 1 & 1 \\
\hline & & Basipod & 2 & 2 & 2 \\
\hline & & Endopod & 5 & 6 & 8 \\
\hline & & Exopod & 5 & 5 & 5 \\
\hline
\end{tabular}

\begin{tabular}{|c|c|c|c|c|c|}
\hline & \multicolumn{2}{|l|}{ Caudal structure } & $\begin{array}{c}\text { Without lobe and with } 2 \\
\text { setae of equal length }\end{array}$ & $\begin{array}{l}\text { Without lobe and with } 2 \\
\text { setae of different lengths }\end{array}$ & $\begin{array}{c}\text { Without lobe and with } 2 \\
\text { setae of equal length }\end{array}$ \\
\hline & & & & Nauplius II & \\
\hline \multirow{6}{*}{ 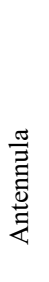 } & Corporal length & & $256,3 \mu \mathrm{m}$ & $185 \mu \mathrm{m}$ & $130 \mu \mathrm{m}$ \\
\hline & Segmentation & & No & No & No \\
\hline & $\mathrm{N}^{\mathrm{o}}$ of articles & & 3 & 3 & 3 \\
\hline & $\mathrm{N}^{0}$ of setae & Segment 1 & 1 & 1 & 0 \\
\hline & & Segment 2 & 2 & 2 & 3 \\
\hline & & Segment 3 & $3+2$ row of small setae & $3+1$ row of small setae & $4+1$ row of 3 small setae \\
\hline \multirow{4}{*}{ 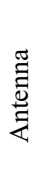 } & $\mathrm{N}^{\mathrm{o}}$ of setae & Coxopod & 1 & 3 & 2 \\
\hline & & Basipod & 2 & 3 & 3 \\
\hline & & Endopod & 5 & 5 & 5 \\
\hline & & Exopod & 7 & 7 & 7 \\
\hline \multirow{8}{*}{ 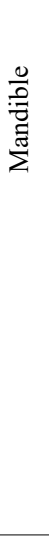 } & $\mathrm{N}^{\circ}$ of setae & Coxopod & 1 & 1 & 1 \\
\hline & & Basipod & 2 & 2 & 2 \\
\hline & & Endopod & 7 & 8 & 8 \\
\hline & & Exopod & 5 & 6 & 5 \\
\hline & Maxillule & & Lacking & Lacking & $\begin{array}{c}1 \text { row of small } \\
\text { setae }\end{array}$ \\
\hline & Maxilla & & Lacking & Lacking & $\begin{array}{c}1 \text { row of small } \\
\text { setae }\end{array}$ \\
\hline & Maxilliped & & Lacking & Lacking & $\begin{array}{c}1 \text { row of small } \\
\text { setae }\end{array}$ \\
\hline & Caudal structure & & $\begin{array}{l}2 \text { lobes, each with } 1 \\
\text { setae of equal length }\end{array}$ & $\begin{array}{l}\text { Without lobe and with } 2 \\
\text { setae of different lengths }\end{array}$ & $\begin{array}{c}2 \text { lobes, each with } 2 \\
\text { setae of different lengths }\end{array}$ \\
\hline & & & & Nauplius III & \\
\hline \multirow{6}{*}{ 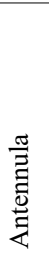 } & Corporal length & & $300,5 \mu \mathrm{m}$ & $223 \mu \mathrm{m}$ & $150 \mu \mathrm{m}$ \\
\hline & Segmentation & & Very incipient & No & Very incipient \\
\hline & $\mathrm{N}^{\mathrm{o}}$ of articles & & 3 & 3 & 3 \\
\hline & $\mathrm{N}^{\mathrm{o}}$ of setae & Segment 1 & 1 & 1 & 0 \\
\hline & & Segment 2 & 2 & 2 & 3 \\
\hline & & Segment 3 & $6+1$ row of small setae & 6 & $7+1$ row of 3 small setae \\
\hline
\end{tabular}


Tab. I. Cont.

\begin{tabular}{|c|c|c|c|c|c|}
\hline \multirow{4}{*}{ 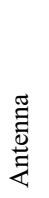 } & \multirow{3}{*}{$\mathrm{N}^{\circ}$ of setae } & \multirow[b]{2}{*}{ Coxopod } & B. poopoensis & B. opaqua & \multirow{2}{*}{$\frac{\text { G. pectinatus }}{3}$} \\
\hline & & & 3 & 3 & \\
\hline & & Basipod & 4 & 4 & 4 \\
\hline & \multirow{6}{*}{$\mathrm{N}^{\circ}$ of setae } & Endopod & 6 & 7 & 7 \\
\hline \multirow{9}{*}{ 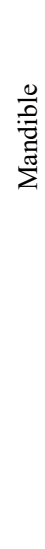 } & & Exopod & 9 & 9 & $9+1$ row of small setae \\
\hline & & Coxopod & 1 & 1 & 1 \\
\hline & & Basipod & 3 & 3 & 3 \\
\hline & & Endopod & 8 & 9 & 10 \\
\hline & & Exopodit & 6 & 6 & 6 \\
\hline & Maxillule & & Lobe with 1 setae & Lacking & Lóbulo con 1 seda \\
\hline & Maxilla & & Lacking & Lacking & $\begin{array}{l}1 \text { hilera de pequeñas } \\
\text { sedas }\end{array}$ \\
\hline & Maxilliped & & Lacking & Lacking & $\begin{array}{l}1 \text { hilera de pequeñas } \\
\text { sedas }\end{array}$ \\
\hline & Caudal structure & & $\begin{array}{l}2 \text { lobes, each with } 2 \\
\text { setae of equal length }\end{array}$ & $\begin{array}{c}2 \text { lobes, one with } 1 \\
\text { setae and other with } 2 \\
\text { setae of different lengths }\end{array}$ & $\begin{array}{c}2 \text { lobes, each } \\
\text { with } 2 \text { setae of different } \\
\text { lengths }\end{array}$ \\
\hline & & & \multicolumn{3}{|c|}{ Nauplius IV } \\
\hline \multirow{7}{*}{$\begin{array}{l}\frac{\pi}{3} \\
\text { 竝 } \\
\text { 宗 }\end{array}$} & Corporal length & & $351,2 \mu \mathrm{m}$ & $260 \mu \mathrm{m}$ & $180 \mu \mathrm{m}$ \\
\hline & Segmentation & & Incipient & No & Incipient \\
\hline & $\mathrm{N}^{\mathrm{o}}$ of articles & & 3 & 3 & 3 \\
\hline & $\mathrm{N}^{\mathrm{o}}$ of setae & Segment 1 & 1 & 1 & 0 \\
\hline & & Segment 2 & 2 & 2 & 3 \\
\hline & & Segment 3 & $10+1$ row of small setae & 12 & $\begin{array}{c}11+1 \text { row of small } \\
\text { setae }\end{array}$ \\
\hline & $\mathrm{N}^{\mathrm{o}}$ of setae & Coxopod & 3 & 3 & 3 \\
\hline \multirow{3}{*}{ 营 } & & Basipod & 5 & 5 & 5 \\
\hline & & Endopod & 7 & 7 & 8 \\
\hline & & Exopod & 10 & 9 & $\begin{array}{c}10+1 \text { row of small } \\
\text { setae }\end{array}$ \\
\hline \multirow{8}{*}{$\begin{array}{l}\frac{0}{0} \\
\frac{7}{\tilde{Z}} \\
\frac{\pi}{\Sigma}\end{array}$} & $\mathrm{N}^{\mathrm{o}}$ de sedas & Coxopod & $1+$ coxal process & $1+$ coxal process & $1+$ coxal process \\
\hline & & Basipod & 3 & 6 & 5 \\
\hline & & Endopod & 9 & 10 & 11 \\
\hline & & Exopod & 6 & 6 & 6 \\
\hline & Maxillule & & 8 setae & 10 setae & 7 setae \\
\hline & Maxilla & & Lacking & Lacking & $\begin{array}{c}1 \text { row of small } \\
\text { setae }\end{array}$ \\
\hline & Maxilliped & & Lacking & Lacking & $\begin{array}{c}1 \text { row of small } \\
\text { setae }\end{array}$ \\
\hline & Caudal structure & & $\begin{array}{l}2 \text { lobes, each with } 2 \\
\text { setae of equal length }\end{array}$ & $\begin{array}{c}2 \text { lobes, one with } 1 \\
\text { setae and other with } 2 \\
\text { setae of different lengths }\end{array}$ & $\begin{array}{c}2 \text { lobes, each with } 2 \\
\text { setae of different lengths }\end{array}$ \\
\hline & & & \multicolumn{3}{|c|}{ Nauplius V } \\
\hline \multirow{6}{*}{ 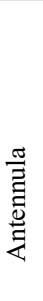 } & Corporal length & & $408,5 \mu \mathrm{m}$ & $298,5 \mu \mathrm{m}$ & $210 \mu \mathrm{m}$ \\
\hline & Segmentation & & Marked & Incipient & Marked \\
\hline & $\mathrm{N}^{\mathrm{o}}$ of articles & & 3 & 3 & 3 \\
\hline & $\mathrm{N}^{o}$ of setae & Segment 1 & 1 & 1 & 0 \\
\hline & & Segment 2 & 2 & 2 & 3 \\
\hline & & Segment 3 & $12+1$ row of small setae & $13+1$ row of small setae & $\begin{array}{c}14+1 \text { row of } 3 \text { small } \\
\text { setae }\end{array}$ \\
\hline
\end{tabular}


Tab. I. Cont.

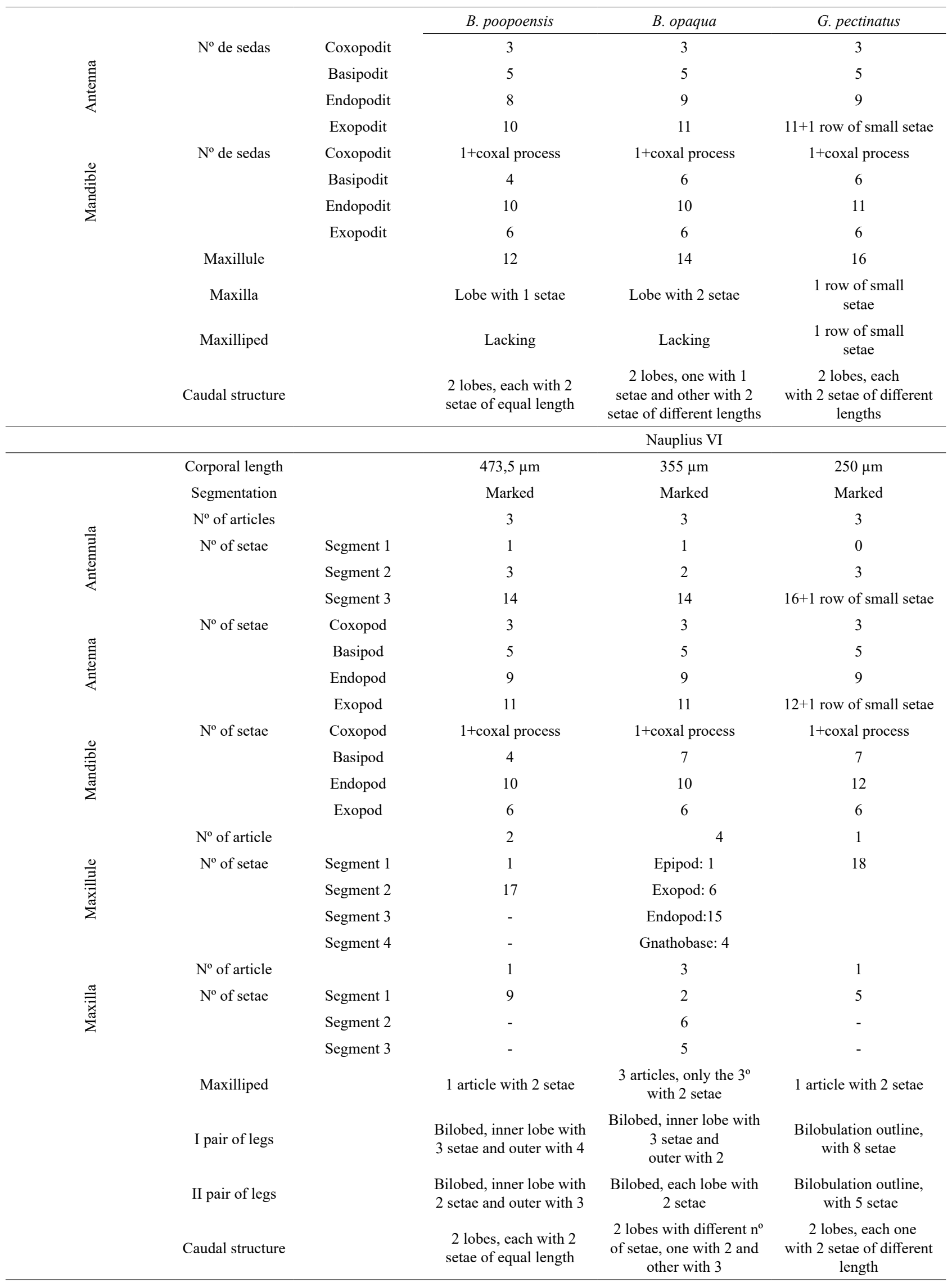


Tab. I. Cont.

\begin{tabular}{|c|c|c|c|c|}
\hline & & B. poopoensis & B. ораquа & G. pectinatus \\
\hline & & \multicolumn{3}{|c|}{ Copepodite I } \\
\hline \multicolumn{2}{|l|}{ Mean corporal length } & $645,6 \mu \mathrm{m}$ & $400 \mu \mathrm{m}$ & $330 \mu \mathrm{m}$ \\
\hline \multicolumn{2}{|l|}{$\begin{array}{l}\mathrm{N}^{\circ} \text { of segments of } \\
\text { antennula }\end{array}$} & 10 & 11 & 10 \\
\hline \multicolumn{2}{|l|}{$\begin{array}{l}\mathrm{N}^{o} \text { of segments of } \\
\text { cephalothorax }\end{array}$} & 4 & 5 & 4 \\
\hline \multicolumn{2}{|l|}{ Pairs of legs } & 2 & 2 & 2 \\
\hline \multicolumn{2}{|l|}{$\begin{array}{l}\text { Pairs of rudimentary } \\
\text { legs }\end{array}$} & $3^{\text {rd }}$ pair & $3^{\text {rd }}$ pair & $3^{\text {rd }}$ pair \\
\hline \multicolumn{2}{|l|}{$\begin{array}{l}\mathrm{N}^{\mathrm{o}} \text { of segments of } \\
\text { abdomen }\end{array}$} & 2 & 1 & 2 \\
\hline \multicolumn{2}{|l|}{$\begin{array}{l}\mathrm{N}^{\circ} \text { of setae of caudal } \\
\text { structure }\end{array}$} & 3 & 6 & 5 \\
\hline & & & Copepodite & \\
\hline \multicolumn{2}{|l|}{ Mean corporal length } & & $570 \mu \mathrm{m}$ & $450 \mu \mathrm{m}$ \\
\hline \multicolumn{2}{|l|}{$\begin{array}{l}\mathrm{N}^{\circ} \text { of segments of } \\
\text { antennula }\end{array}$} & 18 & 16 & 13 \\
\hline \multicolumn{2}{|l|}{$\begin{array}{l}\mathrm{N}^{\circ} \text { of segments of } \\
\text { cephalothorax }\end{array}$} & 5 & 5 & 5 \\
\hline \multicolumn{2}{|l|}{ Pairs of legs } & 3 & 3 & 3 \\
\hline \multicolumn{2}{|l|}{$\begin{array}{l}\text { Pairs of rudimentary } \\
\text { legs }\end{array}$} & $4^{\text {th }}$ pair & $4^{\text {th }}$ pair & $4^{\text {th }}$ par \\
\hline \multicolumn{2}{|l|}{$\begin{array}{l}\mathrm{N}^{\mathrm{o}} \text { of segments of } \\
\text { abdomen }\end{array}$} & 2 & 2 & 2 \\
\hline \multirow{2}{*}{\multicolumn{2}{|c|}{$\begin{array}{l}\mathrm{N}^{\circ} \text { of setae of caudal } \\
\text { structure }\end{array}$}} & 5 & 6 & 6 \\
\hline & & & Copepodite I & \\
\hline \multicolumn{2}{|l|}{ Mean corporal length } & $960,3 \mu \mathrm{m}$ & $710 \mu \mathrm{m}$ & $610 \mu \mathrm{m}$ \\
\hline \multicolumn{2}{|l|}{$\begin{array}{l}\mathrm{N}^{\mathrm{o}} \text { of segments of } \\
\text { antennula }\end{array}$} & 22 & 23 & 21 \\
\hline \multicolumn{2}{|l|}{$\begin{array}{l}\mathrm{N}^{\mathrm{o}} \text { of segments of } \\
\text { cephalothorax }\end{array}$} & 6 & 6 & 6 \\
\hline \multicolumn{2}{|l|}{ Pairs of legs } & 4 & 4 & 4 \\
\hline \multicolumn{2}{|l|}{$\begin{array}{l}\text { Pairs of rudimentary } \\
\text { legs }\end{array}$} & $5^{\text {th }}$ pair & $5^{\text {th }}$ pair & $5^{\text {th }}$ pair \\
\hline \multicolumn{2}{|l|}{$\begin{array}{l}\mathrm{N}^{\mathrm{o}} \text { of segments of } \\
\text { abdomen }\end{array}$} & 2 & 2 & 2 \\
\hline \multirow{2}{*}{\multicolumn{2}{|c|}{$\begin{array}{l}\mathrm{N}^{\circ} \text { of setae of caudal } \\
\text { structure }\end{array}$}} & 5 & 6 & 6 \\
\hline & & & Copepodite I & \\
\hline \multicolumn{2}{|l|}{ Mean corporal length } & $1171,7 \mu \mathrm{m}$ & $827,5 \mu \mathrm{m}$ & $775 \mu \mathrm{m}$ \\
\hline \multicolumn{2}{|l|}{$\begin{array}{l}\mathrm{N}^{\circ} \text { of segments of } \\
\text { antennula }\end{array}$} & 25 & 24 & 24 \\
\hline \multicolumn{2}{|l|}{$\begin{array}{l}\mathrm{N}^{\circ} \text { of segments of } \\
\text { cephalothorax }\end{array}$} & 6 & 6 & 6 \\
\hline \multicolumn{2}{|l|}{ Pairs of legs } & 5 & 5 & 5 \\
\hline \multirow[t]{4}{*}{$\mathrm{N}^{\mathrm{o}}$ of setae leg IV } & Coxopod & & 1 & 2 dorsal small setae \\
\hline & Basipod & 0 & 1 & 1 \\
\hline & Endopod & 6 & 4 & 4 \\
\hline & Exopod & 7 & 7 & 6 \\
\hline \multirow[t]{3}{*}{$\mathrm{N}^{\circ}$ of setae of leg IV $\widehat{\partial}$} & Coxopod & 0 & 0 & 2 dorsal small setae \\
\hline & Basipod & 0 & 1 & 1 \\
\hline & Endopod & 4 & 4 & 4 \\
\hline
\end{tabular}


Tab. I. Cont.

\begin{tabular}{|c|c|c|c|c|c|}
\hline & & & B. poopoensis & B. opaqua & G. pectinatus \\
\hline & Exopod & & 5 & 6 & 6 \\
\hline $\begin{array}{l}\mathrm{N}^{o} \text { of segments of } \\
\text { abdomen }\end{array}$ & & & 3 & 3 & 3 \\
\hline \multirow[t]{2}{*}{$\begin{array}{l}N^{o} \text { of setae caudal } \\
\text { structure }\end{array}$} & & & 6 & 6 & 6 \\
\hline & & & & Copepodite Vq & \\
\hline Mean corporal length & & & $1483,4 \mu \mathrm{m}$ & $1040 \mu \mathrm{m}$ & $1080 \mu \mathrm{m}$ \\
\hline $\begin{array}{l}\mathrm{N}^{\circ} \text { of segments of } \\
\text { antennula }\end{array}$ & & & 25 & 25 & 24 \\
\hline $\begin{array}{l}\mathrm{N}^{o} \text { of segments of } \\
\text { cephalothorax }\end{array}$ & & & 6 & $5^{*}$ & 6 \\
\hline Pairs of legs & & & 5 & 5 & 5 \\
\hline \multirow[t]{4}{*}{$\mathrm{N}^{o}$ of setae of leg V } & Coxopod & & 0 & 1 & $\begin{array}{l}2 \text { rows of dorsal } \\
\text { small setae }\end{array}$ \\
\hline & Basipod & & 1 & 1 & 1 \\
\hline & Endopod & & $\begin{array}{l}\text { Segment 1: } 1 \\
\text { Segment } 2: 7\end{array}$ & $\begin{array}{l}\text { Segment 1: } 0 \\
\text { Segment 2: } 5\end{array}$ & $\begin{array}{l}\text { Segment 1: } 1 \\
\text { Segment 2: } 6\end{array}$ \\
\hline & Exopod & & $\begin{array}{l}\text { Segment 1: } 1 \\
\text { Segment 2: } 5\end{array}$ & $\begin{array}{l}\text { Segment 1: } 1 \\
\text { Segment 2: } 8\end{array}$ & $\begin{array}{l}\text { Segment 1: } 5 \\
\text { Segment 2: } 5\end{array}$ \\
\hline $\begin{array}{l}\mathrm{N}^{o} \text { of segments of } \\
\text { abdomen }\end{array}$ & & & 3 & 3 & 3 \\
\hline \multirow[t]{2}{*}{$\begin{array}{l}\mathrm{N}^{o} \text { of setae caudal } \\
\text { structure }\end{array}$} & & & 6 & 6 & 6 \\
\hline & & & & Copepodite $\mathrm{V} \delta$ & \\
\hline Mean corporal length & & & $1337,4 \mu \mathrm{m}$ & $940 \mu \mathrm{m}$ & $1000 \mu \mathrm{m}$ \\
\hline $\begin{array}{l}\mathrm{N}^{\circ} \text { of segments of } \\
\text { antennula }\end{array}$ & & & 25 & 25 & 24 \\
\hline $\begin{array}{l}\mathrm{N}^{\mathrm{o}} \text { of segments of ceph- } \\
\text { alothorax }\end{array}$ & & & 6 & $* *$ & 6 \\
\hline Pairs of legs & & & 5 & 5 & 5 \\
\hline \multirow[t]{6}{*}{$\mathrm{N}^{\circ}$ of setae of leg $\mathrm{V}$} & Coxopod & & 0 & 0 & $\begin{array}{l}2 \text { rows of dorsal } \\
\text { small setae }\end{array}$ \\
\hline & Basipod & & 0 & 1 & 1 \\
\hline & Endond & Right & $\begin{array}{l}\text { Segment 1: } 0 \\
\text { Segment 2: } 0\end{array}$ & $\begin{array}{l}\text { Segment 1: } 0 \\
\text { Segment 2: } 1\end{array}$ & $\begin{array}{l}\text { Segment 1: } 5 \\
\text { Segment 2: } 5\end{array}$ \\
\hline & Endopod & Left & $\begin{array}{l}\text { Segment 1:0 } \\
\text { Segment 2:0 }\end{array}$ & $\begin{array}{l}\text { Segment 1: } 0 \\
\text { Segment 2: } 0\end{array}$ & $\begin{array}{l}\text { Segment 1: } 5 \\
\text { Segment 2: } 5\end{array}$ \\
\hline & Exopod & Right & $\begin{array}{l}\text { Segment } 1: 1 \\
\text { Segment } 2: 0 \\
\text { Segment } 3: 4\end{array}$ & $\begin{array}{l}\text { Segment } 1: 1 \\
\text { Segment } 2: 1 \\
\text { Segment } 3: 3\end{array}$ & $\begin{array}{c}\text { Segment 1: } 1 \\
\text { Segment 2: } 6 \\
-\end{array}$ \\
\hline & & Left & $\begin{array}{l}\text { Segment 1: } 1 \\
\text { Segment 2: } 4\end{array}$ & $\begin{array}{l}\text { Segment 1: } 1 \\
\text { Segment 2: } 4\end{array}$ & $\begin{array}{l}\text { Segment 1: } 1 \\
\text { Segment 2: } 6\end{array}$ \\
\hline $\begin{array}{l}\mathrm{N}^{\circ} \text { of segments of } \\
\text { abdomen }\end{array}$ & & & 4 & 4 & 4 \\
\hline $\begin{array}{l}\mathrm{N}^{\circ} \text { of setae of structure } \\
\text { caudal }\end{array}$ & & & 6 & 6 & 6 \\
\hline
\end{tabular}

* Information extracted from the copepodite $\mathrm{V} \bigcirc$ drawing of FAIRBRIDGE (1945).

** It is not specified in the text or the drawings of FAIRBRIDGE (1945). 
Other morphological characteristics allowed for distinguishing $B$. poopoensis, such as the number and pattern of setae of the naupliar appendages, the $\mathrm{V}$ pair of legs, the furcal branches, and the number of segments from the different appendages, which are described in detail in Tab. I.

The description of the postembryonic stages of Boeckella poopoensis and the posterior comparison carried out in the present work confirm that this species reaches an important corporal size that is greater than the other centropagid species.

Although the number of setae of the different appendages of B. poopoensis in the immature stages was relatively similar to those of other species of the family, the setae have individual patterns and a characteristic number that is slightly lower than that of other centropagid species, even from the same genus.

The V pair of legs from B. poopoensis indicates a more advanced copepodite that have a morphology similar to that of $B$. opaqua due to its closer relationship between there this species than with G. pectinatus.

The present work contributes to the body of knowledge on the population structure of a copepod species that is relevant to the ecological importance of Neotropical aquatic ecosystems.

Acknowledgements. We thank the Facultad de Ciencias Exactas y Naturales of the Universidad Nacional de La Pampa (Argentina) and the Consejo Nacional de Investigaciones Científicas y Técnicas of Argentina for the financial support of this work, and two anonymous reviewers whose work improved this contribution.

\section{REFERENCES}

BAN, S. 1994. Effect of temperature and food concentration on postembryonic development, egg production and adult body size of calanoid copepod Eurytemora affinis. Journal Plankton Research 16:721-735.

Chapman, M. A. \& Burns, C. 1976. Sexual and other differences in copepodite stages of some New Zealand Calamoecia and Boeckella spp. (Copepoda: Calanoida). Journal of Marine and Freshwater Research 10(1):131-137.

Cicchino, G. 1972. Desarrollo post-embrionario de Notodiaptumus coniferoides (Wright, 1927) y Eucyclops neumanni (Pesta, 1927) (Crustacea, Copepoda). Physis 31(83):585-596.

CzaIKa, S. C. 1982. Identification of nauplii N1-N6 and copepodids CICVI of the Great Lakes calanoid and cyclopoid copepods (Calanoida, Cyclopoida, Copepoda). Journal of Great Lakes Research 8(3):439469.

De los Ríos-Escalante, P. 2011. Morphological variations in Boeckella poopoensis (Marsh, 1906) (Copepoda, Calanoida) in two shallow saline ponds (Chile) and potential relation to salinity gradient. International Journal of Aquatic Science 2(1):80-87.
De los Ríos, P. \& Contreras, P. 2005. Salinity level and occurrence of centropagid copepods (Crustacea, Copepoda, Calanoida) in shallow lakes in Andes Mountains and Patagonian plains, Chile. Polish Journal of Ecology 53(3):445-450.

Echaniz, S. A.; Cabrera, G. C.; Rodríguez, C. \& Vignatti, A. M. 2013. Do temporary lakes vary from year to year? A comparison of limnological parameters and zooplankton from two consecutive annual cycles in an Argentine temporary saline lake. International Journal of Aquatic Science 4(1):44-61.

FAIRBRIDGE, W. S. 1945. West Australian freshwater calanoids (Copepoda) I. Three new species of Boeckella with a description of the developmental stages of B. opaqua $\mathrm{n}$. sp., and a key to the genus. Journal of the Royal Society of Western Australia 29:25-65.

FrYeR, G. 1987. Quantitative and qualitative numbers and reality in the study of living organisms. Freshwater Biology 17:177-189.

Gutiérrez, M.; PAggi, J. \& Gagneten, A. 2010. Fish kairomones alter life cycle and growth of a calanoid copepod. Journal of Plankton Research 32(1):47-55.

Huys, R. \& Boxshall, G. 1991. Copepod evolution. London, The Ray Society. $468 \mathrm{p}$.

Jersabek, C. D.; Goldschmid, A. \& Schabetsberger, R. 1996. Naupliar development of Acanthodiaptomus denticornis (Wierzejski, 1887) and Arctodiaptomus alpinus (Imhof, 1885) (Copepoda: Calanoida) and a comparison with other Diaptomidae. Journal of Plankton Research 18:2027-2061.

JAMIESON, C. 1986. A method for distinguishing the females and late copepodites of three species of Boeckella. New Zealand Journ al of Marine and Freshwater Research 20:153-156.

McKinnon, A. D. \& ARnotT, G. H. 1985. The developmental stages of Gladioferens pectinatus (Brady, 1899) (Copepoda: Calanoida). New Zealand Journal of Marine and Freshwater Research 19:21-42.

Menú-Marque, S.; Morrone, J. \& Locascio de Mitrovich, C. 2000. Distributional patterns of the South American species of Boeckella (Copepoda: Centropagidae): a track analysis. Journal of Crustacean Biology 20(2):262-272.

NAVARRo-CipóLLI, M. 1973. Morfología externa das fases de desenvolvimiento de Diaptomus corderoi Wright, 1936 (Crustacea, Copepoda, Calanoida). Boletim de Zoologia e Biologia Marinha, nova série 30:567-612.

Neveu-Lemaire, M. 1906. Les lacs des hauts plateaux de l'Amérique du Sud. Paris, Imprimerie Nationale. 246p.

Pires de GouvÉa, E. 1980. Estágios do desenvolvimiento naupliar de Notodiaptomus conifer (Sars, 1901) (Copeoda, Calanoida). Ciência e Cultura 32(8):1947-1059.

RAVERA, O. 1953. Gli satdi di sviluppo dei copepodi pelagici del Lago Maggiore. Memorie Dell'Istituto Italiano Di Idrobiologia 7:129-151.

TRUjILLO-Ortiz, A. 1986. Life cycle of the marine calanoid copepod Acartia californiensis Trinast reared under laboratory conditions. CalCOFI Report 27:188-204.

Vignatti, A.; Cabrera, G. \& Echaniz, S. 2016. Biology of Boeckella poopoensis Marsh, 1906 (Copepoda, Calanoida) in natural conditions in temporary saline lakes of the central Argentina. Biota Neotropica 16(2):1-9.

ZINKAI, N. P. 1991. Feeding of nauplius stages of Eudiaptomus gracilis on mixed plastic beads. Journal of Plankton Research 13:437-453.

ZINKAI, N. P. 1994. Feeding of copepodite and adult stages of Eudiaptomus gracilis (Sars, G.O., 1863) (Copepoda, Calanoida) on mixed plastic beads. Crustaceana 66:90-109. 